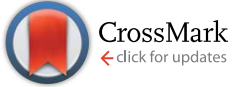

Cite this: RSC Adv., 2017, 7, 6972

Received 13th December 2016

Accepted 5th January 2017

DOI: 10.1039/c6ra28136b

www.rsc.org/advances

\section{A facile, simple, and inexpensive ionic liquid, 1-alkyl-3-methylimidazole chloride, as ligand for the iron(III)-mediated reverse atom transfer radical polymerization of methyl methacrylate}

\begin{abstract}
Xiaohui Liu, ${ }^{*}$ Qian Zhu, Qiuyan Zhang, Yanguang Zhang and Chen Ding
Over the past few years, ionic liquids (ILS) have been widely reported as reaction media for reverse atom transfer radical polymerization (ATRP). In particular, almost all the ILs with the structure [Hmim][RCOO] ( $R$ represents an alkyl group) have been used as ligands for a reverse ATRP system. However, the facile, simple and low-cost ILs, 1-alkyl-3-methylimidazole chloride ([Rmim][CI]), have rarely been employed as ligands for reverse ATRP. In this article, a [Rmim] [Cl] was successfully employed as a ligand for the reverse ATRP of methyl methacrylate with Fe(III) as catalyst and 2,2'-azobisisobutyronitrile as initiator. The key to success is to adjust the $\mathrm{FeCl}_{3} /[\mathrm{Rmim}][\mathrm{Cl}]$ molar ratio value to $1: 1$. The results indicated that the polymerization with $[\mathrm{Rmim}][\mathrm{Cl}]$ as a ligand proceeded in a controlled/"living" fashion, as evidenced by the first-order kinetic plot, low polydispersity index values, and increase in polymer molecular weight with monomer conversion. The effects of various experimental parameters, including different catalysts, reaction temperatures, solvents, and molar ratios of $\mathrm{FeCl}_{3} /[\mathrm{Rmim}][\mathrm{Cl}]$, on the polymerization were investigated in detail. Furthermore, ${ }^{1} \mathrm{H}$ NMR and gel permeation chromatography analyses confirmed the halogen-containing chain-end functionality of the resultant polymer.
\end{abstract}

\section{Introduction}

In the last twenty years, atom transfer radical polymerization (ATRP) has received great attention for preparing polymers with predictable molecular weights and low polydispersity index (PDI) values. ${ }^{1-11}$ In a normal ATRP, a dynamic equilibrium is established by the oxidation-reduction reaction between activator and dormant species. ${ }^{\mathbf{1 2}}$ However, the transition-metal complexes in lower oxidation states are air sensitive and easily oxidized in the presence of even traces of oxygen. Therefore, new ATRP systems, such as supplemental activator and reducing agent atom transfer radical polymerization (SARA ATRP) ${ }^{\mathbf{1 3 , 1 4}}$ reverse ATRP ${ }^{15-17}$ activators (re)generated by electron transfer (A(R)GET) ATRP, ${ }^{18-23}$ and initiators for continuous initiator regeneration (ICAR) ATRP, ${ }^{24-28}$ have been developed to overcome the above drawbacks. In the ATRP derivative systems, high-oxidation-state metals were generally converted to the corresponding lower-oxidation-state complexes with the aid of an additional reducing agent.

Ionic liquids (ILs) are organic salts in the liquid state at or near room temperature, and possess good solubility for transition-metal catalysts. Consequently, ILs have been considered to be environmentally friendly solvents, due to their

School of Materials Science and Engineering, Tianjin Polytechnic University, Tianjin 300387, China. E-mail: luixiaohui@tjpu.edu.cn nonvolatile and nonflammable properties. Furthermore, various ILs have been designed as reaction media or even ligands by varying the structures of cation and anion for ATRP, especially for reverse ATRP. ${ }^{29-33}$

Early in 2000, Carmichael et al. ${ }^{34}$ first reported the use of 1butyl-3-methylimidazolium hexafluorophosphate $\left(\left[\mathrm{C}_{4} \mathrm{mim}\right]\right.$ $\left.\left[\mathrm{PF}_{6}\right]\right)$ as a solvent for the copper(I)-mediated ATRP of methyl methacrylate (MMA). Later, the application of ILs as reaction media for ATRP aroused great interest. In particular, ILs with 1alkyl-3-methylimidazolium ([Rmim], where $\mathrm{R}$ represents an alkyl group) as the cation have been widely used in coppercatalyzed ATRP systems. ${ }^{35-38}$ Matyjaszewski's group investigated the normal ATRP of MMA with various ILs as ligands. ${ }^{39}$ These ILs with [Rmim] as the cations contained different anions such as $\mathrm{Cl}^{-}, \mathrm{Br}^{-}, \mathrm{CO}_{3}{ }^{-}$, and $\mathrm{AlCl}_{4}{ }^{-}$. Furthermore, due to the outstanding advantages of iron catalysts, i.e., low cost, low toxicity, and good biocompatibility, the excellent performance of iron-catalyzed ATRP ILs as reaction media has also been reported. ${ }^{40,41}$ Chen et al. ${ }^{42,43}$ reported the iron(III)/acidic ligandcatalyzed reverse ATRP of acrylonitrile (AN) and methacrylonitrile (MAN) with $[\mathrm{Rmim}]\left[\mathrm{BF}_{4}\right]$ and $[\mathrm{Rmim}]\left[\mathrm{PF}_{6}\right]$ as reaction media, respectively. Generally, when ILs were used as solvents, an organic ligand was usually required in the iron-catalyzed reverse ATRP systems. Meanwhile, the anions of ILs were the expensive $\mathrm{BF}_{4}{ }^{-}$or $\mathrm{PF}_{6}{ }^{-{ }^{44,45}}$ Moreover, the ILs were synthesized via at least two steps (steps 1 and 2 or steps 1 and 3 in Scheme 1). 

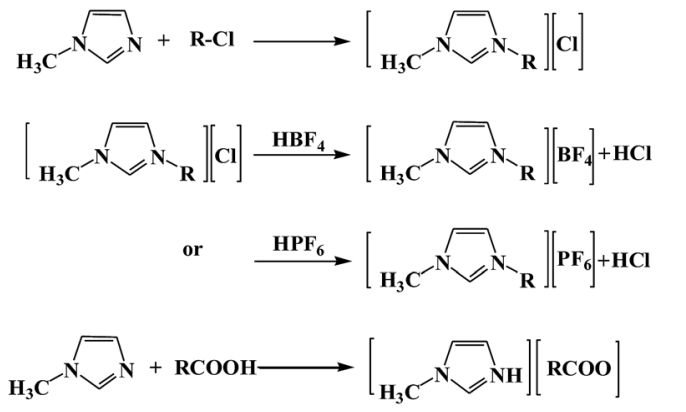

(1) $\left[\right.$ Rmim]][Cl]: $\mathrm{R}=\mathrm{C}_{4} \mathrm{H}_{9}, \mathrm{C}_{6} \mathrm{H}_{13}, \mathrm{C}_{8} \mathrm{H}_{17}, \mathrm{C}_{12} \mathrm{H}_{25}$

(2) $[\mathrm{Rmim}]\left[\mathrm{BF}_{4}\right]: \mathbf{R}=\mathrm{C}_{4} \mathrm{H}_{9}$

(3) $[\mathrm{Rmim}]\left[\mathrm{PF}_{6}\right]: \mathrm{R}=\mathrm{C}_{4} \mathrm{H}_{9}$

(4) [Hmim][RCOO]: $\mathbf{R}=\mathrm{CH}_{3}, \mathrm{C}_{2} \mathrm{H}_{5}, \mathrm{C}_{3} \mathrm{H}_{7}$

Scheme 1 Typical synthetic routes of ILs.

The cheaper [Hmim] [RCOO] (step 4 in Scheme 1) was used for the iron-catalyzed ATRP of $\mathrm{AN}^{46}$ and reverse ATRP of $\mathrm{MAN}^{47}$ without any additional ligand by Chen's group. However, the monomer conversions were relatively low. To avoid the air sensitivity of the low-oxidation-state metal in normal ATRP, other ATRP systems with ILs as reaction media have also been explored, including A(R)GET ATRP, ${ }^{4-52}$ ICAR ATRP, ${ }^{53}$ and single electron transfer-living radical polymerization (SET-LRP). ${ }^{54}$ Likewise, the ILs in these polymerization systems are generally expensive anions $\left(\mathrm{PF}_{6}{ }^{-}, \mathrm{BF}_{4}{ }^{-}, \mathrm{OH}^{-}, \mathrm{HCO}_{3}{ }^{-}, \mathrm{CO}_{3}{ }^{-}, \mathrm{PO}_{4}{ }^{-}\right.$, and $\mathrm{RCOO}^{-}$) or need two or more preparation steps (Scheme 1). To the best of our knowledge, the use of the facile, simple, and cheap ILs, 1-alkyl-3-methylimidazole chloride ([Rmim] [Cl], step 1 in Scheme 1) as a reaction medium or ligand for reverse ATRP has rarely been reported. We find it curious that there are few reports on $[\mathrm{Rmim}][\mathrm{Cl}]$ as reaction media or ligands for reverse ATRP, especially in an Fe(III)-catalyzed system.

The current work is aimed to demonstrate the feasibility of using the facile, uncomplicated, and inexpensive ILs ([Rmim] [Cl]) as the ligand for Fe(III)-catalyzed reverse ATRP of MMA. Kinetic studies confirmed the controlled/"living" radical polymerization characteristics. The effects of various experimental parameters on the polymerizations were investigated in detail.

\section{Experimental}

\section{Materials}

MMA (99\%), ethyl methacrylate (EMA), and butyl methacrylate (BMA), were washed with $5 \% \mathrm{NaOH}$ to remove the inhibitor (hydroquinone), washed with distilled water several times, and freshly distilled under reduced pressure after drying over $\mathrm{Na}_{2} \mathrm{SO}_{4}$. 2,2-Azobisisobutyronitrile (AIBN) was recrystallized twice from ethanol prior to use. 1-Butyl-3-methylimidazole chloride $\left(\left[\mathrm{C}_{4} \mathrm{mim}\right][\mathrm{Cl}]\right)$, 1-hexyl-3-methylimidazole chloride $\left(\left[\mathrm{C}_{6} \mathrm{mim}\right]\right.$ $[\mathrm{Cl}])$, 1-octyl-3-methylimidazole chloride $\left(\left[\mathrm{C}_{8} \mathrm{mim}\right][\mathrm{Cl}]\right)$, and 1dodecyl-3-methylimidazole chloride $\left(\left[\mathrm{C}_{12} \mathrm{mim}\right][\mathrm{Cl}]\right)$ were prepared following the method in the literature. ${ }^{55}$ Acetonitrile (MeCN, 99\%), $N, N$-dimethylformamide (DMF, 99\%), dimethyl sulfoxide (DMSO, 99\%), toluene (99\%), and dichloromethane $\left(\mathrm{CH}_{2} \mathrm{Cl}_{2}, 99 \%\right)$ were dried over $\mathrm{Na}_{2} \mathrm{SO}_{4}$ before use. Ferric chloride $\left(\mathrm{FeCl}_{3}, 99 \%\right.$, Aladdin), ferric bromide $\left(\mathrm{FeBr}_{3}, 99 \%\right.$, Aladdin), and ferric sulfate $\left(\mathrm{Fe}_{2}\left(\mathrm{SO}_{4}\right)_{3}\right.$, $99 \%$ ) were used as received without further purification.

\section{Polymerization}

A typical polymerization was as follows. $\mathrm{MMA}$ and $\mathrm{FeCl}_{3}$ were added to a Schlenk tube with a magnetic stirrer bar. The tube was immersed in liquid nitrogen for one minute. Subsequently, AIBN, IL, and MeCN were rapidly added into the tube. Then the mixture was subject to three freeze-pump-thaw cycles to remove oxygen. Finally, the tube was charged with nitrogen before being sealed with a rubber septum, and placed in an oil bath at $70{ }^{\circ} \mathrm{C}$. After the desired reaction time, the polymerization mixture was cooled by ice water, exposed to air, and the contents were then diluted with MeCN. When the mixture became a homogenous solution, the polymer was precipitated in a large excess of ethyl alcohol. The final product was separated by filtration, and dried under vacuum at $45{ }^{\circ} \mathrm{C}$ until constant weight was achieved.

\section{Characterization}

The monomer conversions were determined gravimetrically. The number-average molecular weight $\left(M_{\mathrm{n}, \mathrm{GPC}}\right)$ and PDI values of the obtained poly(methyl methacrylate) (PMMA) samples were determined by gel permeation chromatography (GPC). The GPC system was equipped with a Waters 510 HPLC pump and a Waters 2414 RI detector and used three Waters Ultrastyragel columns $(500,103$, and 105) in THF at a flow rate of $1.0 \mathrm{~mL}$ $\mathrm{min}^{-1}$. PMMA standards were used to calibrate the columns. ${ }^{1} \mathrm{H}$ NMR spectra of PMMA samples were recorded on a Bruker 300 $\mathrm{MHz}$ spectrometer using $\mathrm{CDCl}_{3}$ as the solvent and tetramethylsilane (TMS) as the internal standard.

\section{Results and discussion}

\section{[Rmim] $\mathrm{Cl}$ as ligand for the $\mathrm{FeCl}_{3}$-catalyzed reverse ATRP of MMA}

As noted previously, the common, facile, and cheap ionic liquids, $[\mathrm{Rmim}][\mathrm{Cl}]$ were rarely reported as reaction media or ligands for reverse ATRP. ${ }^{56}$ The ligand is very important for controlled/"living" radical polymerization, as reported by Anastasaki et al. ${ }^{57}$ Therefore, we firstly examined the feasibility of the $\mathrm{Fe}(\mathrm{III}) /[\mathrm{Rmim}][\mathrm{Cl}]$-catalyzed reverse ATRP of MMA by changing the amount of $[\mathrm{Rmim}][\mathrm{Cl}]$, i.e., the effect of the concentration of a typical IL $\left[\mathrm{C}_{12} \mathrm{mim}\right][\mathrm{Cl}]$ was investigated in detail under similar polymerization conditions at $70{ }^{\circ} \mathrm{C}$. As shown in Table 1, when a large amount of IL is added into the polymerization (the ratio of $\left[\mathrm{FeCl}_{3}\right]_{0} /\left[\mathrm{C}_{12} \mathrm{mim}\right][\mathrm{Cl}]_{0}=2: 40$, entry 1 ), the monomer conversion reaches only $12 \%$ within $42 \mathrm{~h}$. Moreover, the measured molecular weight value $\left(M_{\mathrm{n}, \mathrm{GPC}}\right)$ is much larger than the theoretical one $\left(M_{\mathrm{n}, \mathrm{th}}\right)$, and the PDI value reaches 1.85 . The results suggested that $\mathrm{Fe}(\mathrm{III})$ retarded or even inhibited the polymerization. By decreasing the amount of IL to a ratio of $\left[\mathrm{FeCl}_{3}\right]_{0} /\left[\mathrm{C}_{12} \mathrm{mim}\right][\mathrm{Cl}]_{0}=2: 2$, it is found, surprisingly, that the monomer conversion increases to $76 \%$ within a shorter duration $(8 \mathrm{~h})$, and the PDI value is lowered to 1.28 (entry 2). In addition, the measured molecular weight 
Table 1 Effect of IL concentration on the reverse ATRP of MMA in bulk ${ }^{a}$

\begin{tabular}{|c|c|c|c|c|c|c|c|}
\hline Entry & {$\left[\mathrm{FeCl}_{3}\right]_{0} /[\mathrm{IL}]_{0}$} & Time (h) & Conv. $(\%)$ & $M_{\mathrm{n}, \mathrm{th}}(\mathrm{Da})$ & $M_{\mathrm{n}, \mathrm{GPC}}(\mathrm{Da})$ & Initiat. effic. & PDI \\
\hline 1 & $2 / 40$ & 41 & 12 & 2000 & 9200 & 0.22 & 1.85 \\
\hline 2 & $2 / 2$ & 8 & 76 & 12800 & 12900 & 0.99 & 1.28 \\
\hline
\end{tabular}

Table 2 Effect of different ILs on the reverse ATRP of MMA in bulk ${ }^{a}$

\begin{tabular}{|c|c|c|c|c|c|c|}
\hline Entry & $\mathrm{IL}$ & Conv. (\%) & $M_{\mathrm{n}, \mathrm{th}}(\mathrm{Da})$ & $M_{\mathrm{n}, \mathrm{GPC}}(\mathrm{Da})$ & Initiat. effic. & PDI \\
\hline 1 & {$\left[\mathrm{C}_{4} \mathrm{mim}\right][\mathrm{Cl}]$} & 56 & 9500 & 10200 & 0.93 & 1.23 \\
\hline 2 & {$\left[\mathrm{C}_{6} \mathrm{mim}\right][\mathrm{Cl}]$} & 67 & 11300 & 12200 & 0.93 & 1.25 \\
\hline 4 & {$\left[\mathrm{C}_{12} \mathrm{mim}\right][\mathrm{Cl}]$} & 76 & 12800 & 12900 & 0.99 & 1.28 \\
\hline
\end{tabular}

$M_{\mathrm{n}, \mathrm{GPC}}$ is close to the theoretical $M_{\mathrm{n} \text {,th }}$ one. Clearly, the polymerization process proceeds in a controlled/"living" fashion. With a further decrease in $\left[\mathrm{C}_{12} \mathrm{mim}\right][\mathrm{Cl}]_{0}$ to a ratio of $\left[\mathrm{FeCl}_{3}\right]_{0} /$ $\left[\mathrm{C}_{12} \mathrm{mim}\right][\mathrm{Cl}]_{0}$ to $2: 1$, the rate of polymerization is lowered again (only $24 \%$ monomer conversion within $33 \mathrm{~h}$, entry 3 ). Therefore, by adding too much or too little IL into the polymerization system it is not possible to obtain a high rate of polymerization and control of the polymerization. Under the investigated conditions, only the reverse ATRP of MMA with $\left[\mathrm{FeCl}_{3}\right]_{0} /[\mathrm{IL}]_{0}=2: 2$ shows a controlled/“living” radical polymerization (CRP) process. The controlled/"living" characteristics are confirmed by a measured molecular weight value close to the theoretical one and a low PDI value. These findings are in agreement with the results of Bai et al. ${ }^{58}$ In particular, as clearly demonstrated by Table 1, with an optimized molar ratio of $2: 2$ (entry 2) the IL may readily coordinate to $\mathrm{FeCl}_{3}$. With large amount of IL, with a molar ratio of $2: 40$ (entry 1), the $\mathrm{FeCl}_{3} / \mathrm{IL}$ complex could be preferentially destroyed, while with $\mathrm{FeCl}_{3} / \mathrm{IL}$ molar ratio of $2: 1$, free $\mathrm{FeCl}_{3}$ metal compound could potentially retard or inhibit the radical polymerization of MMA (entry 3).

To gain further insight into the polymerization system, the effect of the IL alkyl chain length on the reverse ATRP of MMA was studied. A series of polymerization reactions with $\left[\mathrm{C}_{4} \mathrm{mim}\right]$ $[\mathrm{Cl}],\left[\mathrm{C}_{6} \mathrm{mim}\right][\mathrm{Cl}],\left[\mathrm{C}_{8} \mathrm{mim}\right][\mathrm{Cl}]$, and $\left[\mathrm{C}_{12} \mathrm{mim}\right][\mathrm{Cl}]$ as ligands was carried out under the same conditions, and the polymerization results are presented in Table 2 . The monomer conversions reach $56 \%, 67 \%, 67 \%$, and $76 \%$ within $8 \mathrm{~h}$ with $\left[\mathrm{C}_{4} \mathrm{mim}\right][\mathrm{Cl}]$, $\left[\mathrm{C}_{6} \mathrm{mim}\right][\mathrm{Cl}],\left[\mathrm{C}_{8} \mathrm{mim}\right][\mathrm{Cl}]$, and $\left[\mathrm{C}_{12} \mathrm{mim}\right][\mathrm{Cl}]$ as ligands, respectively. The PDI values of the resultant polymer remain in a low range, from 1.23 to 1.28 . Fig. 1 shows the dependence of monomer conversion and $M_{\mathrm{n}, \mathrm{GPC}}$ for the reverse ATRP of MMA in bulk on the IL alkyl chain length. Obviously, the longer the alkyl chain length, the higher the monomer conversion and the PMMA molecular weight. This may originate from the fact that an IL ligand with a longer alkyl chain can more easily coordinate with the catalyst $\mathrm{FeCl}_{3}$, thus inducing a faster rate of polymerization than an IL ligand with a shorter alkyl chain. This

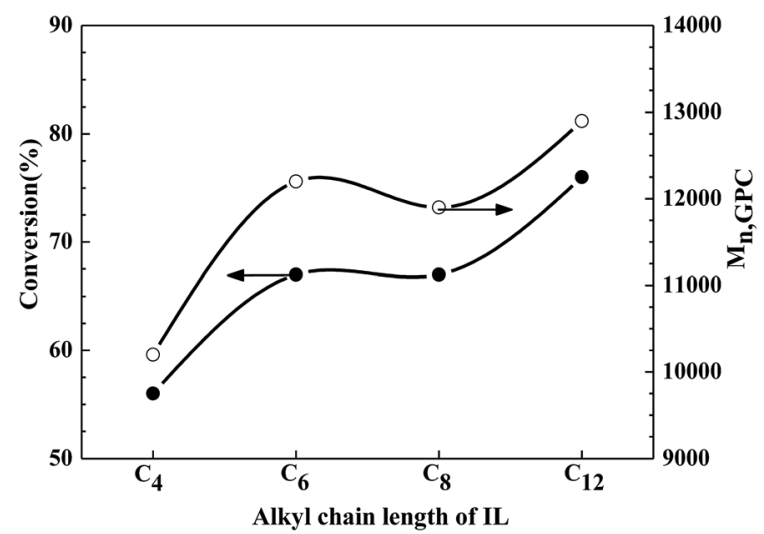

Fig. 1 Dependence of conversion and $M_{n, G P C}$ on the alkyl chain length of IL for the reverse ATRP of MMA in bulk. Reaction conditions: $[\mathrm{MMA}]_{0} /[\mathrm{AIBN}]_{0} /\left[\mathrm{FeCl}_{3}\right]_{0} /[\mathrm{IL}]_{0}=200: 1: 2: 2,[\mathrm{MMA}]_{0}=9.4 \mathrm{~mol} \mathrm{~L}^{-1}$, $T=70^{\circ} \mathrm{C}$.

indicates a strong dependence of polymerization on the alkyl chain length of IL. Thus, $\left[\mathrm{C}_{12} \mathrm{mim}\right][\mathrm{Cl}]$ is an optimal ligand for the reverse ATRP of MMA in bulk, yielding the fastest rate of polymerization and the highest molecular weight.

To further confirm the controlled/"living" nature of the $\mathrm{Fe}(\mathrm{III}) /[\mathrm{Rmim}][\mathrm{Cl}]$-catalyzed reverse ATRP of MMA in bulk, kinetic studies were performed with the molar ratio of $[\mathrm{MMA}]_{0} /$ $[\mathrm{AIBN}]_{\mathrm{o}} /\left[\mathrm{FeCl}_{3}\right]_{\mathrm{o}} /\left[\mathrm{C}_{12} \mathrm{mim}\right][\mathrm{Cl}]_{0}=200: 1: 2: 2$ in bulk at $70{ }^{\circ} \mathrm{C}$. The kinetic plot of $\ln \left([\mathrm{M}]_{0} /[\mathrm{M}]\right)$ versus time is shown in Fig. 2 . The plot shows an approximately straight line, proving that the concentration of propagating radicals was stable, and the side reactions can be ignored during the polymerization. ${ }^{\mathbf{5 9 , 6 0}}$ In addition, an induction period of $c a .3 \mathrm{~h}$ is observed. The induction period probably originated from the following factors. ${ }^{61,62}$ On the one hand, $\mathrm{Fe}^{3+}$ and $\mathrm{Fe}^{2+}$ required a certain time to establish dynamic equilibrium at the beginning of the polymerization. On the other hand, AIBN decomposed relatively slowly in the initial stage of the polymerization, and the primary 


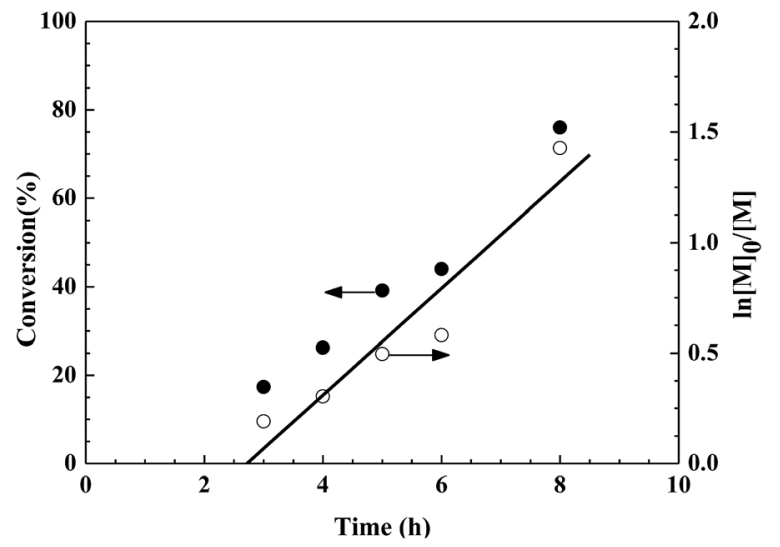

Fig. 2 Kinetic plots of $\ln \left([M]_{0} /[M]\right)$ versus reaction time for the reverse ATRP of MMA in bulk. Reaction conditions: $[\mathrm{MMA}]_{0} /[\mathrm{AIBN}]_{0} /\left[\mathrm{FeCl}_{3}\right]_{0} /$ $\left[\mathrm{C}_{12} \mathrm{mim}\right][\mathrm{Cl}]_{0}=200: 1: 2: 2,[\mathrm{MMA}]_{0}=9.4 \mathrm{~mol} \mathrm{~L}^{-1}, T=70{ }^{\circ} \mathrm{C}$.

radical generated from $\mathrm{AIBN}$ reacted completely with $\mathrm{FeCl}_{3}$ to form the activator species $\mathrm{Fe}^{2+}$, leading to the result that the concentration of the reactive radical species was too low to initiate the polymerization at a noticeable rate. The $M_{\mathrm{n} \text {,th }}$ of PMMA obtained from reverse ATRP may be calculated based on the following equation: ${ }^{63}$

$$
M_{\mathrm{n}, \mathrm{th}}=\frac{[\mathrm{MMA}]_{0} \times \text { conv. } \times M_{\mathrm{MMA}}}{2[\mathrm{AIBN}]_{0}\left(1-\mathrm{e}^{-k_{\mathrm{d}} t}\right)}
$$

where $[\mathrm{MMA}]_{0}$ and $[\mathrm{AIBN}]_{0}$ correspond to the initial concentrations of MMA and AIBN, respectively, conv. is the monomer conversion, $M_{\mathrm{MMA}}$ is the molecular weight of MMA, the value of $k_{\mathrm{d}}$ for AIBN is $3.1 \times 10^{-5}$ at $70{ }^{\circ} \mathrm{C},{ }^{64}$ and $t$ corresponds to the reaction time. The dependences of $M_{\mathrm{n}}$ and PDI of the obtained polymer on the monomer conversion are illustrated in Fig. 3. The measured molecular weight $M_{\mathrm{n}, \mathrm{GPC}}$ values increase linearly from 3900 to 12900 with monomer conversion, and are close to the theoretical $M_{\mathrm{n}, \mathrm{th}}$ ones. The PDI values of the obtained polymers decrease from 1.45 to 1.16 in the first stage, and then remain almost unchanged. The trend in PDI values from high to

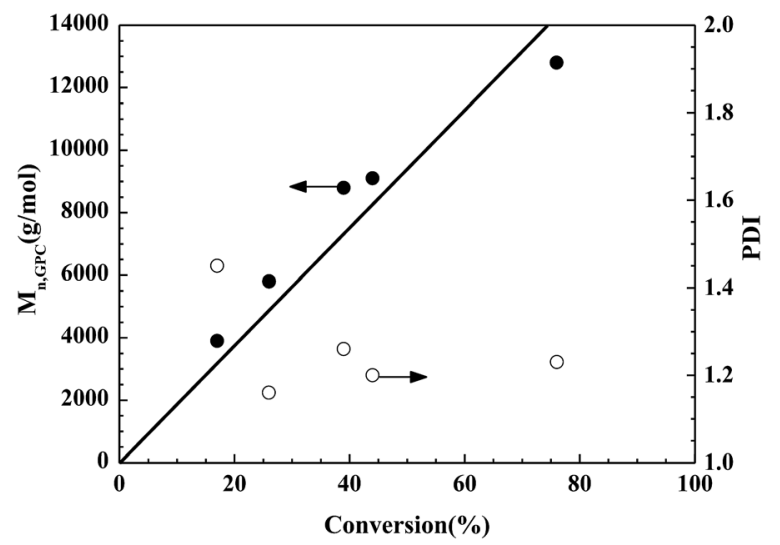

Fig. 3 Evolution of $M_{n}$ (-theoretical) and PDI with monomer conversion for the reverse ATRP of MMA in bulk. Reaction conditions: $[\mathrm{MMA}]_{0} /[\mathrm{AIBN}]_{0} /\left[\mathrm{FeCl}_{3}\right]_{0} /\left[\mathrm{C}_{12} \mathrm{mim}\right][\mathrm{Cl}]_{0}=200: 1: 2: 2,[\mathrm{MMA}]_{0}=$ $9.4 \mathrm{~mol} \mathrm{~L}^{-1}, T=70{ }^{\circ} \mathrm{C}$. low is in accord with the CRP principle. ${ }^{65}$ The change in the GPC traces displays the trend visually (Fig. 4). The curves are narrow and symmetrical. Moreover, the traces of the obtained typical polymers shift toward a shorter elution time, indicating the increase in $M_{\mathrm{n}, \mathrm{GPC}}$ with monomer conversion. ${ }^{66}$ All the above observations suggest that the $\mathrm{Fe}(\mathrm{III})-[\mathrm{Rmim}][\mathrm{Cl}]$-catalyzed reverse ATRP of MMA progressed in a controlled/"living" manner. ${ }^{67}$

\section{Effect of different catalysts on the reverse ATRP of MMA}

The effect of different Fe(III) catalysts on the reverse ATRP of MMA in bulk was also examined, and the results are summarized in Table 3 . With $\mathrm{Fe}_{2}\left(\mathrm{SO}_{4}\right)_{3}$ as the catalyst to conduct the $\mathrm{Fe}(\mathrm{III})-\left[\mathrm{C}_{12} \mathrm{mim}\right][\mathrm{Cl}]$-catalyzed reverse ATRP of MMA, the polymerization reaches only $19 \%$ monomer conversion within $24 \mathrm{~h}$ (entry 1). The measured molecular weight value $M_{\mathrm{n}, \mathrm{GPC}}(7900)$ of the resultant PMMA is much larger than the theoretical one $M_{\text {n,th }}$ (1900). Meanwhile, the PDI value (4.93) is the highest among the three systems. As the catalyst $\left(\mathrm{Fe}_{2}\left(\mathrm{SO}_{4}\right)_{3}\right)$ and initiator (AIBN) do not contain halogen elements, the polymerization cannot proceed via the ATRP mechanism. Thus, for the $\mathrm{Fe}_{2}\left(\mathrm{SO}_{4}\right)_{3}-\left[\mathrm{C}_{12} \mathrm{mim}\right][\mathrm{Cl}]$-catalyzed polymerization of MMA, there is a loss of control, which is different from the result for ethyl-2bromoisobutyrate $/ \mathrm{CuSO}_{4} \cdot 5 \mathrm{H}_{2} \mathrm{O} / N, N, N^{\prime}, N^{\prime}, N^{\prime \prime}$-pentamethyldiethylenetriamine-initiated CRP of MMA by Zhu's group. ${ }^{68}$ In contrast, with the bromine-containing catalyst $\mathrm{FeBr}_{3}$ instead of $\mathrm{Fe}_{2}\left(\mathrm{SO}_{4}\right)_{3}$, the bulk polymerization yielded $70 \%$ monomer conversion after $8 \mathrm{~h}$ (entry 2). Obviously, the rate of polymerization increased greatly, while the PDI value (1.35) of the resultant PMMA was lowered, and the measured molecular weight value $\left(M_{\mathrm{n}, \mathrm{GPC}}=14500\right)$ is closer to the theoretical one $\left(M_{\mathrm{n}, \mathrm{th}}=11800\right)$. Nevertheless, the PDI value is slightly higher than that with a chlorine-containing catalyst, $\mathrm{FeCl}_{3}(\mathrm{PDI}=1.28$, entry 3). To sum up, $\mathrm{FeCl}_{3}$ is the most suitable catalyst for the investigated systems, as evidenced from the results that the corresponding polymerization yields 76\% monomer conversion, and produces well-defined PMMA with a controlled

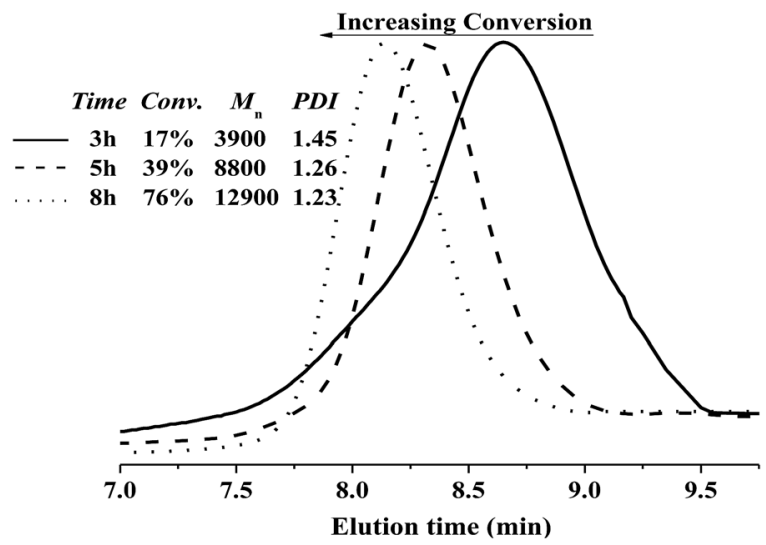

Fig. 4 The change in the GPC traces for the reverse ATRP of MMA in bulk at different monomer conversions: $17 \%, 39 \%$, and $76 \%$. Reaction conditions: $[\mathrm{MMA}]_{0} /[\mathrm{AlBN}]_{0} /\left[\mathrm{FeCl}_{3}\right]_{0} /\left[\mathrm{C}_{12} \mathrm{mim}\right][\mathrm{Cl}]_{0}=200: 1: 2: 2$, $[M M A]_{0}=9.4 \mathrm{~mol} \mathrm{~L}^{-1}, T=70^{\circ} \mathrm{C}$. 
Table 3 Effect of different catalysts on the reverse ATRP of MMA in bulk

\begin{tabular}{llllllr}
\hline Entry & Catalyst & Time $(\mathrm{h})$ & Conv. $(\%)$ & $M_{\mathrm{n}, \mathrm{th}}(\mathrm{Da})$ & $M_{\mathrm{n}, \mathrm{GPC}}(\mathrm{Da})$ & Initiat. effic. \\
\hline 1 & $\mathrm{Fe}_{2}\left(\mathrm{SO}_{4}\right)_{3}$ & 24 & 19 & 1900 & 7900 & PDI \\
2 & $\mathrm{FeBr}_{3}$ & 8 & 70 & 11800 & 14500 & 0.24 \\
3 & $\mathrm{FeCl}_{3}$ & 8 & 76 & 12800 & 12900 & 0.81 \\
${ }^{a}[\mathrm{MMA}]_{0} /[\mathrm{AIBN}]_{0} /[\mathrm{catalyst}]_{0} /\left[\mathrm{C}_{12} \mathrm{mim}\right][\mathrm{Cl}]_{0}=200: 1: 2: 2,[\mathrm{MMA}]_{0}=9.4 \mathrm{~mol} \mathrm{~L}^{-1}, T=70^{\circ} \mathrm{C}$. & & \\
\end{tabular}

$M_{\mathrm{n}, \mathrm{GPC}}(12800)$ close to $M_{\mathrm{n}, \mathrm{th}}(12$ 900) and the lowest PDI value (1.28).

\section{$\mathrm{FeCl}_{3}-\left[\mathrm{C}_{12} \mathrm{mim}\right][\mathrm{Cl}]$-catalyzed reverse ATRP for different monomers}

According to the above results, the $\mathrm{Fe}(\mathrm{III})-\left[\mathrm{C}_{12} \mathrm{mim}\right][\mathrm{Cl}]$-catalyzed reverse ATRP of MMA with $\left[\mathrm{FeCl}_{3}\right]_{0} /[\mathrm{IL}]_{0}=2: 2$ is a CRP process. To investigate the generality of this approach for different monomers, EMA and BMA were selected instead of MMA as the monomer to carry out the $\mathrm{Fe}(\mathrm{III})-\left[\mathrm{C}_{12} \mathrm{mim}\right][\mathrm{Cl}]$-catalyzed reverse ATRP under the same reaction conditions. As shown in Table 4, the monomer conversion reaches $76 \%$ after $8 \mathrm{~h}$ for the MMA system, and the measured molecular weight $M_{\mathrm{n}, \mathrm{GPC}}$ value is very close to the theoretical one (entry 1). Likewise, the EMA and BMA polymerization systems achieve moderate-to-high rates of polymerization $(58 \%$ and $70 \%$ monomer conversions, respectively), and the measured molecular weight $M_{\mathrm{n}, \mathrm{GPC}}$ values (14 500 and 18 800, respectively) of the resultant EMA and BMA polymers are higher than their corresponding theoretical ones (10 700 and 10800 , respectively). Importantly, their corresponding polymers give narrow molecular weight distribution values (PDI $=1.18$ and 1.22, respectively). Therefore, the EMA and BMA polymerization systems proceed according to the CRP principle, confirming that the polymerization approach can be successfully extended to other monomers.

\section{Effect of various solvents on the reverse ATRP of MMA}

It is necessary to investigate the effect of various mediums including bulk, DMSO, DMF, $\mathrm{MeCN}, \mathrm{CH}_{2} \mathrm{Cl}_{2}$, and toluene on the $\mathrm{Fe}(\mathrm{III})-\left[\mathrm{C}_{12} \mathrm{mim}\right][\mathrm{Cl}]$-catalyzed reverse ATRP of MMA at $70{ }^{\circ} \mathrm{C}$. The molar ratio of $[\mathrm{MMA}]_{0} /[\mathrm{AIBN}]_{0} /\left[\mathrm{FeCl}_{3}\right]_{0} /[\mathrm{IL}]_{0}$ was set to $200: 1: 2: 2$, and the original volume ratio of MMA to solvent was $2: 1$. Clearly, compared with the bulk polymerization yielding $76 \%$ monomer conversion after $8 \mathrm{~h}$ and the controlled PMMA with a measured $M_{\mathrm{n}, \mathrm{GPC}}$ very close to the theoretical $M_{\mathrm{n} \text {,th }}$ and PDI $=1.28$ (entry 1, Table 5), the polymerization in DMSO shows the lowest monomer conversion (23\%) after $20 \mathrm{~h}$ and gives a less-controlled PMMA, with a $M_{\mathrm{n}, \mathrm{GPC}}(7600)$ three times larger than the theoretical $M_{\mathrm{n}, \mathrm{th}}$ (2300, entry 2). Similar results are found in Fe(II)-catalyzed normal ATRP in DMSO without any ligand, as reported by Matyjaszewski et al. ${ }^{69}$ which is possibly attributable to the fact that DMSO coordinates much more strongly to the Fe catalyst and substitutes for halide ligands, thereby weakening the catalytic activity and inducing a loss of control over the polymerization. In contrast, the excellent solvent systems for PMMA, i.e., DMF, MeCN, and $\mathrm{CH}_{2} \mathrm{Cl}_{2}$, can reach relatively higher monomer conversions within the same reaction time of $20 \mathrm{~h}$ (entries 3-5): in particular, $\mathrm{MeCN}$ and $\mathrm{CH}_{2} \mathrm{Cl}_{2}$ reach up to 91\% monomer conversion (entries 4 and 5). Moreover, for the less polar solvent toluene, the monomer conversion reaches $80 \%$ after 20 h (entry 6 ), suggesting that this less polar solvent

Table 4 Reverse ATRP for different monomers in bulk ${ }^{a}$

\begin{tabular}{|c|c|c|c|c|c|c|c|}
\hline Entry & Monomer & Time (h) & Conv. (\%) & $M_{\mathrm{n}, \text { th }}(\mathrm{Da})$ & $M_{\mathrm{n}, \mathrm{GPC}}(\mathrm{Da})$ & Initiat. effic. & PDI \\
\hline 1 & MMA & 8 & 76 & 12800 & 12900 & 0.99 & 1.28 \\
\hline 2 & EMA & 9 & 58 & 10700 & 14500 & 0.74 & 1.18 \\
\hline
\end{tabular}

Table 5 Effect of various solvents on the reverse ATRP of MMA ${ }^{a}$

\begin{tabular}{lllllr}
\hline Entry & Solvent & Conv. (\%) & $M_{\mathrm{n}, \mathrm{th}}(\mathrm{Da})$ & $M_{\mathrm{n}, \mathrm{GPC}}(\mathrm{Da})$ & Initiat. effic. \\
\hline $1^{b}$ & Bulk & 76 & 12800 & 12900 & 0.99 \\
2 & DMSO & 23 & 2500 & 7600 & 0.33 \\
3 & DMF & 90 & 9000 & 11200 & 0.80 \\
4 & MeCN & 91 & 10100 & 15200 & 0.66 \\
5 & $\mathrm{CH}_{2} \mathrm{Cl}_{2}$ & 91 & 10100 & 14500 & 0.69 \\
6 & Toluene & 80 & 8400 & 12500 & 1.26 \\
\end{tabular}

${ }_{b}^{a}[\mathrm{MMA}]_{0} /[\mathrm{AIBN}]_{0} /\left[\mathrm{FeCl}_{3}\right]_{0} /\left[\mathrm{C}_{12} \mathrm{mim}\right][\mathrm{Cl}]_{0}=200: 1: 2: 2, \mathrm{MMA} /$ solvent $=2: 1(\mathrm{v} / \mathrm{v}),[\mathrm{MMA}]_{0}=9.4 \mathrm{~mol} \mathrm{~L}{ }^{-1}, T=70{ }^{\circ} \mathrm{C}$, reaction time $=20 \mathrm{~h}$.

${ }^{b}$ Reaction time $=8 \mathrm{~h}$. 
Table 6 Effect of $\left[\mathrm{AIBN}_{0} /\left[\mathrm{FeCl}_{3}\right]_{0} /[\mathrm{IL}]_{0}\right.$ on the reverse ATRP of MMA in $\mathrm{MeCN}^{a}$

\begin{tabular}{|c|c|c|c|c|c|c|c|}
\hline Entry & {$[\mathrm{MMA}]_{\mathrm{o}} /[\mathrm{AIBN}]_{0} /\left[\mathrm{FeCl}_{3}\right]_{0} /[\mathrm{IL}]_{0}$} & Time (h) & Conv. $(\%)$ & $M_{\mathrm{n}, \mathrm{th}}(\mathrm{Da})$ & $M_{\mathrm{n}, \mathrm{GPC}}(\mathrm{Da})$ & Initiat. effic. & PDI \\
\hline 1 & $200 / 1 / 0.5 / 0.5$ & 16 & 99 & 11900 & 22600 & 0.53 & 1.91 \\
\hline 2 & $200 / 1 / 1 / 1$ & 16 & 92 & 11100 & 18500 & 0.60 & 1.44 \\
\hline 4 & $200 / 1 / 3 / 3$ & 46 & 50 & 5000 & 10500 & 0.48 & 1.23 \\
\hline 5 & $200 / 1 / 4 / 4$ & 46 & 50 & 5000 & 8800 & 0.57 & 1.20 \\
\hline
\end{tabular}

has almost no effect on the polymerization system. On the basis of the above results that $\mathrm{CH}_{2} \mathrm{Cl}_{2}$ and MeCN have a significant impact on the polymerization, the non-halogen solvent $\mathrm{MeCN}$ is thus chosen as the optimal solvent for the $\mathrm{Fe}(\mathrm{III})-\left[\mathrm{C}_{12} \mathrm{mim}\right][\mathrm{Cl}]$ catalyzed reverse ATRP of MMA. It is noteworthy that the measured $M_{\mathrm{n}, \mathrm{GPC}}$ values are much larger than the theoretical $M_{\mathrm{n}, \mathrm{th}}$ ones: that is, the initiator efficiency ( $f$ ) based on $f=M_{\mathrm{n}, \mathrm{th}} /$ $M_{\mathrm{n}, \mathrm{GPC}}$ is lowered as the polymerization is conducted in the solvent. This may be due to the occurrence of coupling reactions of primary radicals in the initial stages of the polymerizations in various solvents. However, all investigated polymerizations consisting of bulk and solution systems produced polymers with lower PDI results (1.20-1.29), showing the high controllability of the employed $\mathrm{Fe}(\mathrm{III})-\left[\mathrm{C}_{12} \mathrm{mim}\right][\mathrm{Cl}]$ catalytic system for methacrylate monomers.

\section{Effect of $[\mathrm{AIBN}]_{0} /\left[\mathrm{FeCl}_{3}\right]_{0} /[\mathrm{IL}]_{0}$ on the reverse ATRP of MMA}

For an efficient reverse ATRP system, it is necessary to use the minimum amount of metal in expectation of a high rate of polymerization and for good control of the polymerization. As demonstrated in Table 6 , the rate of polymerization can be changed by altering the molar ratio of $[\mathrm{AIBN}]_{0} /\left[\mathrm{FeCl}_{3}\right]_{0} /[\mathrm{IL}]_{0}$. The polymerization reaches $99 \%$ and $92 \%$ monomer conversion within $16 \mathrm{~h}$ for $[\mathrm{AIBN}]_{0} /\left[\mathrm{FeCl}_{3}\right]_{0} /[\mathrm{IL}]_{0}=1: 0.5: 0.5$ and $1: 1: 1$, respectively (entries $1-2$ ). For $[\mathrm{AIBN}]_{0} /\left[\mathrm{FeCl}_{3}\right]_{0} /[\mathrm{IL}]_{0}=$ $1: 2: 2$, the polymerization gives $91 \%$ monomer conversion within $20 \mathrm{~h}$ (entry 3 ). Decreasing $[\mathrm{AIBN}]_{\mathrm{o}} /\left[\mathrm{FeCl}_{3}\right]_{\mathrm{o}} /[\mathrm{IL}]_{0}$ down to $1: 3: 3$ and $1: 4: 4$, the polymerizations yield only $50 \%$ conversion within $46 \mathrm{~h}$ (entries 4 and 5 ). Thus the $\left[\mathrm{FeCl}_{3}\right]_{\mathrm{o}} /[\mathrm{IL}]_{0}$ value is a crucial experimental parameter for the rate of polymerization, and adding an excess of catalyst obviously decreases monomer conversions from ca. $100 \%$ to $50 \%$ (Fig. 5). The same rule can be observed from the changes in the PDI and molecular weight values with different $\left[\mathrm{FeCl}_{3}\right]_{0} /[\mathrm{IL}]_{0}$ values, as exhibited in Table 6, Fig. 5, and 6. With low $\left[\mathrm{FeCl}_{3}\right]_{0} /$ $[\mathrm{IL}]_{0}$ values of $0.5: 0.5$ and $1: 1$, the corresponding PDI values are relatively higher (1.91 and 1.44 , respectively). With a decrease in $[\mathrm{AIBN}]_{0} /\left[\mathrm{FeCl}_{3}\right]_{0} /[\mathrm{IL}]_{0}$ down to $1: 2: 2,1: 3: 3$, and $1: 4: 4$, the corresponding PDI values remain in a narrow range of 1.20-1.23. For the case of molecular weight, the final polymers obtained from five catalytic systems show a straight drop from 22600 to 8800 with the variation in $\left[\mathrm{FeCl}_{3}\right]_{0} /[\mathrm{IL}]_{0}$ values. Furthermore, it is worthwhile noting the deviation between the measured molecular weight value and the corresponding theoretical one, i.e., the initiator efficiency (Fig. 6).

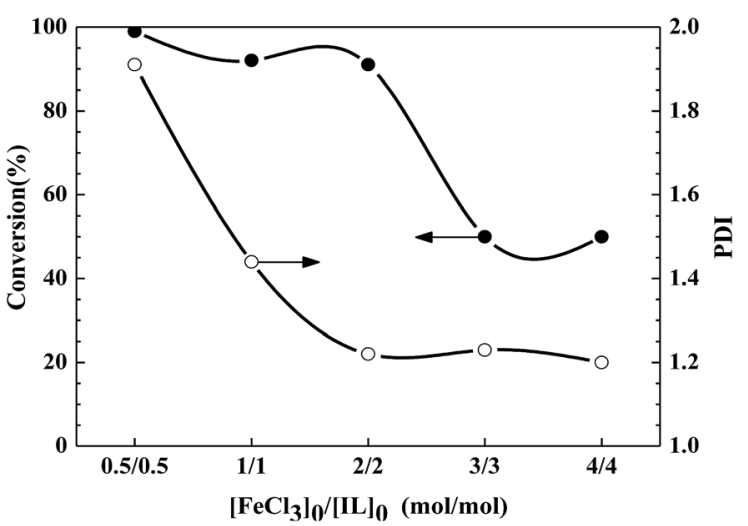

Fig. 5 Dependence of conversion and PDI on the ratio of $\left[\mathrm{FeCl}_{3}\right]_{0} /[\mathrm{IL}]_{0}$ for the reverse ATRP of MMA in MeCN. Reaction conditions: [MMA] / $[\mathrm{AlBN}]_{0} /\left[\mathrm{FeCl}_{3}\right]_{0} /\left[\mathrm{C}_{12} \mathrm{mim}\right][\mathrm{Cl}]_{0}=200: 1: 2: 2, \mathrm{MMA} / \mathrm{MeCN}=2: 1(\mathrm{v} /$ v), $[\mathrm{MMA}]_{0}=9.4 \mathrm{~mol} \mathrm{~L}^{-1}, T=70^{\circ} \mathrm{C}$.

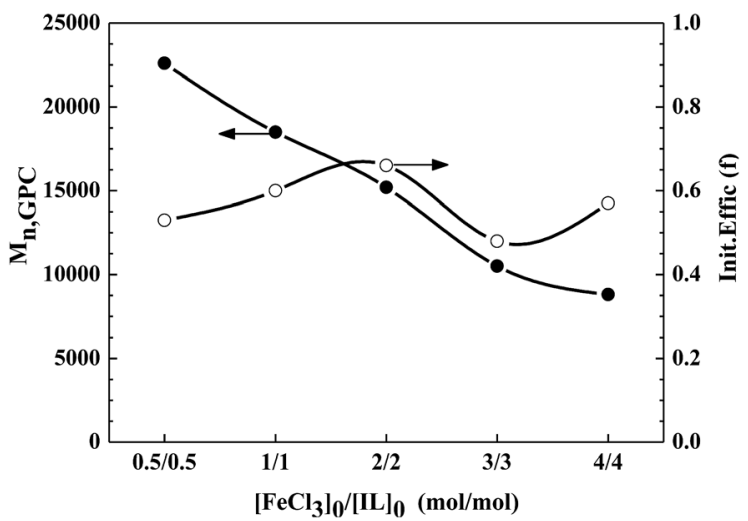

Fig. 6 Dependence of $M_{n, G P C}$ and initiator efficiency $(f)$ on the ratio of $\left[\mathrm{FeCl}_{3}\right]_{0} /[\mathrm{IL}]_{0}$ for the reverse ATRP of MMA in MeCN. Reaction conditions: $[\mathrm{MMA}]_{0} /[\mathrm{AIBN}]_{0} /\left[\mathrm{FeCl}_{3}\right]_{0} /\left[\mathrm{C}_{12} \mathrm{mim}\right][\mathrm{Cl}]_{0}=200: 1: 2: 2, \mathrm{MMA} /$ $\mathrm{MeCN}=2: 1(\mathrm{v} / \mathrm{v}),[\mathrm{MMA}]_{0}=9.4 \mathrm{~mol} \mathrm{~L}^{-1}, T=70^{\circ} \mathrm{C}$.

For example, for $\left[\mathrm{FeCl}_{3}\right]_{0} /[\mathrm{IL}]_{0}=0.5: 0.5$ and $1: 1$, the measured $M_{\mathrm{n}, \mathrm{GPC}}$ values (22 600 and 18500 , respectively) of the obtained polymers are higher than their corresponding theoretical ones (11 900 and 11 100, respectively). Among the molar ratios investigated, the polymerization shows the highest initiator efficiency (0.66) with a molar ratio of $\left[\mathrm{FeCl}_{3}\right]_{0} /$ $[\mathrm{IL}]_{0}=2: 2$. Therefore, all the results suggest that selecting a suitable molar ratio of $\left[\mathrm{FeCl}_{3}\right]_{0} /[\mathrm{IL}]_{0}=2: 2$ is extremely important for the reverse ATRP of MMA. 
Table 7 Effect of different temperature on the reverse ATRP of MMA ${ }^{a}$

\begin{tabular}{llllllr}
\hline Entry & Temperature $\left({ }^{\circ} \mathrm{C}\right)$ & Time $(\mathrm{h})$ & Conv. $(\%)$ & $M_{\mathrm{n}, \mathrm{th}}(\mathrm{Da})$ & $M_{\mathrm{n}, \mathrm{GPC}}(\mathrm{Da})$ & Initiat. effic. \\
\hline 1 & 60 & 52 & 50 & 5000 & 11100 & PDI \\
2 & 70 & 16 & 92 & 11100 & 18500 & 0.45 \\
3 & 11 & 94 & 9400 & 13400 & 0.60 \\
${ }^{a}[\mathrm{MMA}]_{0} /[\mathrm{AIBN}]_{0} /\left[\mathrm{FeCl}_{3}\right]_{0} /\left[\mathrm{C}_{12} \mathrm{mim}\right][\mathrm{Cl}]_{0}=200: 1: 1: 1, \mathrm{MMA} / \mathrm{MeCN}=2: 1(\mathrm{v} / \mathrm{v}),[\mathrm{MMA}]_{0}=9.4 \mathrm{~mol} \mathrm{~L}^{-1}$. &
\end{tabular}

\section{Effect of reaction temperature on the reverse ATRP of MMA}

Generally, increasing the reaction temperature can enhance the decomposition rate of radical initiators and the rate of polymerization, and thus shorten the polymerization duration. ${ }^{70}$ Three polymerization reactions were conducted and compared in $\mathrm{MeCN}$ at $60{ }^{\circ} \mathrm{C}, 70{ }^{\circ} \mathrm{C}$, and $90{ }^{\circ} \mathrm{C}$ under the same reaction conditions and the results are summarized in Table 7 . The rate of polymerization increases with increasing temperature from $60{ }^{\circ} \mathrm{C}$ to $90{ }^{\circ} \mathrm{C}$, as evidenced by the increasing monomer conversion (from $50 \%$ to $94 \%$ ) and the shortening of the polymerization time from $52 \mathrm{~h}$ to $11 \mathrm{~h}$. When the polymerization is performed at a relatively low temperature $\left(60{ }^{\circ} \mathrm{C}\right.$, entry 1$)$, it gives only $50 \%$ monomer conversion after $52 \mathrm{~h}$, and the measured molecular weight value $M_{\mathrm{n}, \mathrm{GPC}}(11000)$ of the polymer is much larger than the theoretical one $M_{\mathrm{n}, \mathrm{th}}$ (5000). In contrast, when the polymerization is performed at a relatively high temperature $\left(90{ }^{\circ} \mathrm{C}\right.$, entry 3$)$, it gives $94 \%$ monomer conversion after a shorter polymerization time $(11 \mathrm{~h})$. In addition, the PDI values (1.34-1.44) of the obtained polymers remain low at the three polymerization temperatures, indicating that the polymerization can be successfully conducted over a wide temperature range $\left(60-90^{\circ} \mathrm{C}\right)$.

\section{End-group analysis of the resultant PMMA}

The chemical structure of the obtained PMMA was characterized by ${ }^{1} \mathrm{H}$ NMR spectroscopy. Fig. 7 illustrates the representative ${ }^{1} \mathrm{H}$ NMR spectrum of the well-defined PMMA with $M_{\mathrm{n}}=$

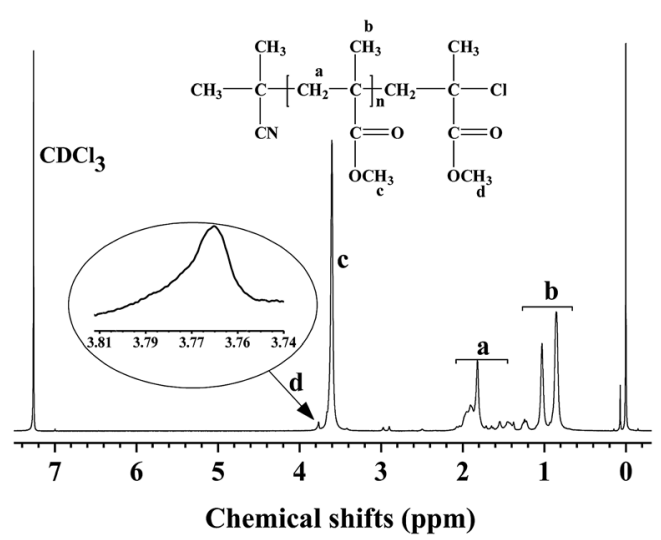

Fig. $7{ }^{1} \mathrm{H}$ NMR spectrum of PMMA obtained from the reverse ATRP of MMA in bulk. Reaction conditions: $[\mathrm{MMA}]_{0} /[\mathrm{AIBN}]_{0} /\left[\mathrm{FeCl}_{3}\right]_{0} /\left[\mathrm{C}_{12} \mathrm{mim}\right]$ $[\mathrm{Cl}]_{0}=200: 1: 2: 2,[\mathrm{MMA}]_{0}=9.4 \mathrm{~mol} \mathrm{~L}^{-1}$, reaction time $=4 \mathrm{~h}$, monomer conversion $=26 \%, T=70^{\circ} \mathrm{C}$.
7600 and PDI $=1.16$. The signals at $0.66-1.30,1.32-2.18$, and 3.46-3.72 ppm are attributed to the protons of the methyl groups $\left(\mathrm{CH}_{3}\right.$, peak b), methylene groups $\left(\mathrm{CH}_{2}\right.$, peak a), and methoxy groups $\left(\mathrm{OCH}_{3}\right.$, peak c), respectively. Moreover, the absorption at 3.74-3.81 is attributed to the protons of $\mathrm{OCH}_{3}$ next to the halogen chain end (peak d), proving the presence of the halogen-containing end group, $\mathrm{CH}_{2} \mathrm{CCl}\left(\mathrm{CH}_{3}\right)\left(\mathrm{COOCH}_{3}\right)$, which agrees with the work reported by Zhu's group. ${ }^{71}$ The $M_{\mathrm{n}, \mathrm{NMR}}$ value of PMMA can be estimated from the ratio of the methylene protons (peak a) to the terminal ones (peak d). The estimated $M_{\mathrm{n}, \mathrm{NMR}}$ value (4900) is slightly lower than the theoretical molecular weight value $M_{\mathrm{n}, \mathrm{th}}$ (7300) and the measured molecular weight value $M_{\mathrm{n}, \mathrm{GPC}}(7600)$. Overall, the results confirmed the distinct controlled/"living" characteristics of the polymerization.

\section{Conclusions}

A small amount of facile, simple, and inexpensive IL ([Rmim] [Cl]) was successfully used as a ligand for the Fe(III)-catalyzed reverse ATRP of MMA. Polymerization kinetic studies confirmed the living/controlled radical polymerization characteristics, as evidenced by the first-order kinetics of polymerization, linear increase in $M_{\mathrm{n}}$ with monomer conversion, controlled $M_{\mathrm{n}}$ close to $M_{\mathrm{n} \text {,th }}$ values, and low PDI values. The polymerization was studied in detail in terms of different alkyl chain lengths of IL (from $\mathrm{C}_{4}$ to $\mathrm{C}_{12}$ ), concentration of IL, catalyst, solvent, molar ratio of $\mathrm{FeCl}_{3} /[\mathrm{Rmim}][\mathrm{Cl}]$, and reaction temperature. Longer alkyl chain lengths of IL and a higher polymerization temperature can accelerate the rate of polymerization. With a suitable molar ratio of $\left[\mathrm{FeCl}_{3}\right]_{0} /[\mathrm{IL}]_{0}=2: 2$, the bulk polymerization achieved a controlled/"living" radical polymerization process with a high molecular weight $\left(M_{\mathrm{n}, \mathrm{th}}=12800\right.$ and $M_{\mathrm{n}, \mathrm{GPC}}=$ 12 900) and initiator efficiency $(f=0.99)$, and low PDI value (PDI $=1.28$ ). In addition, the polymerization system can be successfully extended to other vinyl monomers. The polymerizations in different solvents, including DMSO, DMF, MeCN, $\mathrm{CH}_{2} \mathrm{Cl}_{2}$, and toluene, gave varied control of molecular weight and PDI values, and showed that MeCN can be the best solvent for the polymerization system. Moreover, the halogencontaining chain-end functionality of the resultant PMMA was confirmed by GPC and ${ }^{1} \mathrm{H}$ NMR analyses.

\section{Acknowledgements}

The authors thank the National Natural Science Foundation of China (No. 21074127) for financial support. 


\section{Notes and references}

1 K. Matyjaszewski, Macromolecules, 2012, 45, 4015-4039.

2 J. Ran, L. Wu, Z. Zhang and T. Xu, Prog. Polym. Sci., 2013, 39, 124-144.

3 A. Pal and S. Pal, $R S C A d v$., 2016, 6, 2958-2965.

4 H. Zhou, W. Jiang, N. An, Q. P. Zhang, S. D. Xiang, L. P. Wang and J. Tang, RSC Adv., 2015, 5, 42728-42735.

5 C. Zhou, S. S. Qian, X. J. Li, F. Yao, J. Forsythe and G. D. Fu, RSC Adv., 2014, 4, 54631-54640.

6 M. Zhang, Q. Xiong, W. Shen and Q. Zhang, RSC Adv., 2014, 4, 30566-30572.

7 Q. Zhang, X. D. Tang, T. S. Wang, F. Q. Yu, W. J. Guo and M. S. Pei, $R S C A d v$., 2014, 4, 24240-24247.

8 P. Mandal and N. Singha, RSC Adv., 2014, 4, 213-215.

9 J. C. Theriot, C. H. Lim, H. Yang, M. D. Ryan, C. B. Musgrave and G. M. Miyake, Science, 2016, 352, 1082-1086.

10 C. Boyer, N. A. Corrigan, K. Jung, D. Nguyen, T.-K. Nguyen, N. N. M. Adnan, S. Oliver, S. Shanmugam and J. Yeow, Chem. Rev., 2016, 116, 1803-1949.

11 C. Boyer, A. H. Soeriyadi, P. B. Zetterlund and M. R. Whittaker, Macromolecules, 2011, 44, 8028-8033.

12 J. S. Wang and K. Matyjaszewski, J. Am. Chem. Soc., 1995, 117, 5614-5615.

13 A. Anastasaki, V. Nikolaou and D. M. Haddleton, Polym. Chem., 2016, 7, 1002-1026.

14 A. Anastasaki, V. Nikolaou, G. Nurumbetov, P. Wilson, K. Kempe, J. F. Quinn, T. P. Davis, M. R. Whittaker and D. M. Haddleton, Chem. Rev., 2015, 116, 835-877.

15 Y. P. Jiao, J. S. Jiang, H. T. Zhang, K. Y. Shi and H. Q. Zhang, Eur. Polym. J., 2014, 54, 95-108.

16 O. S. Taskin, G. Yilmaz, M. A. Tasdelen and Y. Yagci, Polym. Int., 2014, 63, 902-907.

17 Y. J. Chen, B. J. Wu, F. S. Wang, M. H. Chi, J. T. Chen and C. H. Peng, Macromolecules, 2015, 48, 6832-6838.

18 L. F. Zhang, Z. P. Cheng, S. P. Shi, Q. H. Li and X. L. Zhu, Polymer, 2008, 49, 3054-3059.

19 J. Miao, H. J. Jiang, L. F. Zhang, Z. Q. Wu, Z. P. Cheng and X. L. Zhu, RSC Adv., 2011, 2, 840-847.

20 Y. H. Yu, X. H. Liu, D. Jia, B. W. Cheng, Y. L. Ren, F. J. Zhang, H. N. Li, P. Chen and S. Xie, J. Polym. Sci., Part A: Polym. Chem., 2013, 51, 1690-1694.

21 Y. H. Yu, X. H. Liu, D. Jia, B. W. Cheng, F. J. Zhang, P. Chen and S. Xie, Polymer, 2013, 54, 148-154.

22 J. Y. Peng, M. Q. Ding, Z. P. Cheng, L. F. Zhang and X. L. Zhu, RSC Adv., 2015, 5, 104733-104739.

23 L. J. Bai, L. F. Zhang, Z. P. Cheng and X. L. Zhu, Polym. Chem., 2012, 3, 2685-2697.

24 X. H. Liu, J. Wang, F. J. Zhang, S. L. An, Y. L. Ren, Y. H. Yu, P. Chen and S. Xie, J. Polym. Sci., Part A: Polym. Chem., 2012, 50, 4358-4364.

25 X. H. Liu, J. Wang, J. S. Yang, S. L. An, Y. L. Ren, Y. H. Yu and P. Chen, J. Polym. Sci., Part A: Polym. Chem., 2012, 50, 19331940.

26 X. W. Jiang, L. F. Zhang, Z. P. Cheng and X. L. Zhu, Macromol. Rapid Commun., 2016, 37, 1337-1343.
27 X. W. Jiang, J. Wu, L. F. Zhang, Z. P. Cheng and X. L. Zhu, Macromol. Rapid Commun., 2014, 35, 1879-1885.

28 T. Guo, L. F. Zhang, X. Q. Pan, X. H. Li, Z. P. Cheng and X. L. Zhu, Polym. Chem., 2013, 4, 3725-3734.

29 B. Tadeusz and K. Przemysław, J. Polym. Sci., Part A: Polym. Chem., 2005, 43, 3454-3459.

30 S. M. Gong, H. Y. Ma and X. H. Wan, Polym. Int., 2006, 55, 1420-1425.

31 E. J. Tang, K. D. Du, X. Y. Feng, M. Yuan, S. J. Liu and D. S. Zhao, Eur. Polym. J., 2015, 66, 228-235.

32 P. Kubisa, Prog. Polym. Sci., 2004, 29, 3-12.

33 A. Anastasaki, V. Nikolaou, G. Nurumbetov, N. P. Truong, G. S. Pappas, N. G. Engelis, J. F. Quinn, M. R. Whittaker, T. P. Davis and D. M. Haddleton, Macromolecules, 2015, 48, 5140-5147.

34 A. J. Carmichael, D. M. Haddleton, S. A. F. Bon and K. R. Seddon, Chem. Commun., 2000, 1237-1238.

35 T. Biedroń and P. Kubisa, Polym. Int., 2003, 52, 1584-1588. 36 H. Y. Ma, X. H. Wan, X. F. Chen and Q. F. Zhou, J. Polym. Sci., Part A: Polym. Chem., 2005, 41, 143-151.

37 H. Y. Ma, X. H. Wan, X. F. Chen and Q. F. Zhou, Polymer, 2003, 44, 5311-5316.

38 S. J. Ding, M. Radosz and Y. Shen, Macromolecules, 2005, 38, 5921-5928.

39 T. Sarbu and K. Matyjaszewski, Macromol. Chem. Phys., 2001, 202, 3379-3391.

40 Z. J. Deng, L. H. Qiu, L. J. Bai, Y. X. Zhou, B. C. Lin, J. Zhao, Z. P. Cheng, X. L. Zhu and F. Yan, J. Polym. Sci., Part A: Polym. Chem., 2012, 50, 1605-1610.

41 L. J. Bai, S. Q. Huang, W. X. Wang, H. Xu, H. Chen, Y. Z. Niu and M. H. Wang, Polym. Int., 2015, 64, 1754-1761.

42 H. Chen, R. J. Qu, C. N. Ji, C. M. Sun and C. H. Wang, J. Polym. Sci., Part A: Polym. Chem., 2008, 46, 2701-2707.

43 Y. Liang, H. Chen and W. Y. Zhou, J. Macromol. Sci., Part A: Pure Appl.Chem., 2009, 46, 759-764.

44 H. Chen, Y. Liang, M. L. Wang, P. L. Lv and Y. H. Xuan, Chem. Eng. J., 2009, 147, 297-301.

45 H. Chen, C. H. Wang, D. L. Liu, M. Wang and C. N. Ji, J. Appl. Polym. Sci., 2011, 122, 3298-3302.

46 H. Chen, R. J. Qu, C. M. Sun, C. N. Ji, C. H. Wang, L. Ying, N. Jiang, F. Xiu and L. F. Chen, Polymer, 2008, 49, 34243427.

47 H. Chen, Y. F. Meng, Y. Liang, Z. X. Lu and P. L. Lv, J. Mater. Res., 2009, 24, 1880-1885.

48 H. Chen, D. L. Liu, Y. T. Song, R. J. Qu and C. H. Wang, Polym. Adv. Technol., 2011, 22, 1513-1517.

49 H. Chen, L. F. Chen, C. H. Wang and R. J. Qu, J. Polym. Sci., Part A: Polym. Chem., 2011, 49, 1046-1049.

50 G. X. Wang, M. Lu, L. C. Liu, H. Wu and M. Zhong, J. Appl. Polym. Sci., 2013, 128, 3077-3083.

51 Z. Deng, J. Guo, L. Qiu, Y. Zhou, L. Xia and F. Yan, Polym. Chem., 2012, 3, 2436-2443.

52 X. Y. Du, J. L. Pan, M. T. Chen, L. F. Zhang, Z. P. Cheng and X. L. Zhu, Chem. Commun., 2014, 50, 9266-9269.

53 G. X. Wang, M. Lu and H. Wu, Polymer, 2012, 53, 1093-1097. 54 J. Ma, H. Chen, M. Zhang and M. M. Yu, J. Polym. Sci., Part A: Polym. Chem., 2012, 50, 609-613. 
55 J. G. Huddleston and R. D. Rogers, Chem. Commun., 1998, 1765-1766.

56 T. Welton, Chem. Rev., 1999, 99, 2071-2084.

57 A. Anastasaki, C. Waldron, P. Wilson, R. Mchale and D. M. Haddleton, Polym. Chem., 2013, 4, 2672-2675.

58 L. J. Bai, W. X. Wang, H. Chen, L. F. Zhang, Z. P. Cheng and X. L. Zhu, RSC Adv., 2015, 5, 62577-62584.

59 L. F. Zhang, Z. P. Cheng, Y. T. Lü and X. L. Zhu, Macromol. Rapid Commun., 2009, 30, 543-547.

60 B. J. Zhang, X. Y. Jiang, L. F. Zhang, Z. P. Cheng and X. L. Zhu, Polym. Chem., 2015, 6, 6616-6622.

61 G. H. Zhu, L. F. Zhang, Z. B. Zhang, J. Zhu, Y. F. Tu, Z. P. Cheng and X. L. Zhu, Macromolecules, 2011, 44, 3233-3239.

62 L. F. Zhang, J. Miao, Z. P. Cheng and X. L. Zhu, Macromol. Rapid Commun., 2010, 31, 275-280.

63 J. S. Wang and K. Matyjaszewski, Macromolecules, 1995, 28, $7572-7573$.
64 Z. G. Xue, D. He and X. L. Xie, Polym. Chem., 2015, 6, 16601687.

65 X. H. Liu, H. N. Li, F. J. Zhang, S. Xie, Z. J. Liu and Y. G. Li, Chin. J. Polym. Sci., 2015, 33, 362-370.

66 V. S. Vo, S. Mahouchechergui, J. Babinot, V. H. Nguyen, S. Naili and B. Carbonnier, RSC Adv., 2016, 6, 89322-89327.

67 X. H. Liu, H. N. Li, F. J. Zhang, Q. Zhu, X. H. Hu, W. L. Di, S. Zhao and Y. G. Li, Polymer, 2016, 107, 170-176.

68 J. F. Zhao, W. X. Wang, L. J. Bai, L. L. Zhou, Z. P. Cheng, Z. B. Zhang and X. L. Zhu, Polym. Chem., 2012, 3, 3220-3223.

69 Y. Wang and K. Matyjaszewski, Macromolecules, 2010, 43, 4003-4005.

70 Z. J. Deng, L. H. Qiu, L. J. Bai, Y. X. Zhou, B. C. Lin, J. Zhao, Z. P. Cheng, X. L. Zhu and F. Yan, J. Polym. Sci., Part A: Polym. Chem., 2012, 50, 1605-1610.

71 G. Wang, X. L. Zhu, Z. P. Cheng and J. Zhu, Eur. Polym. J., 2003, 39, 2161-2165. 